
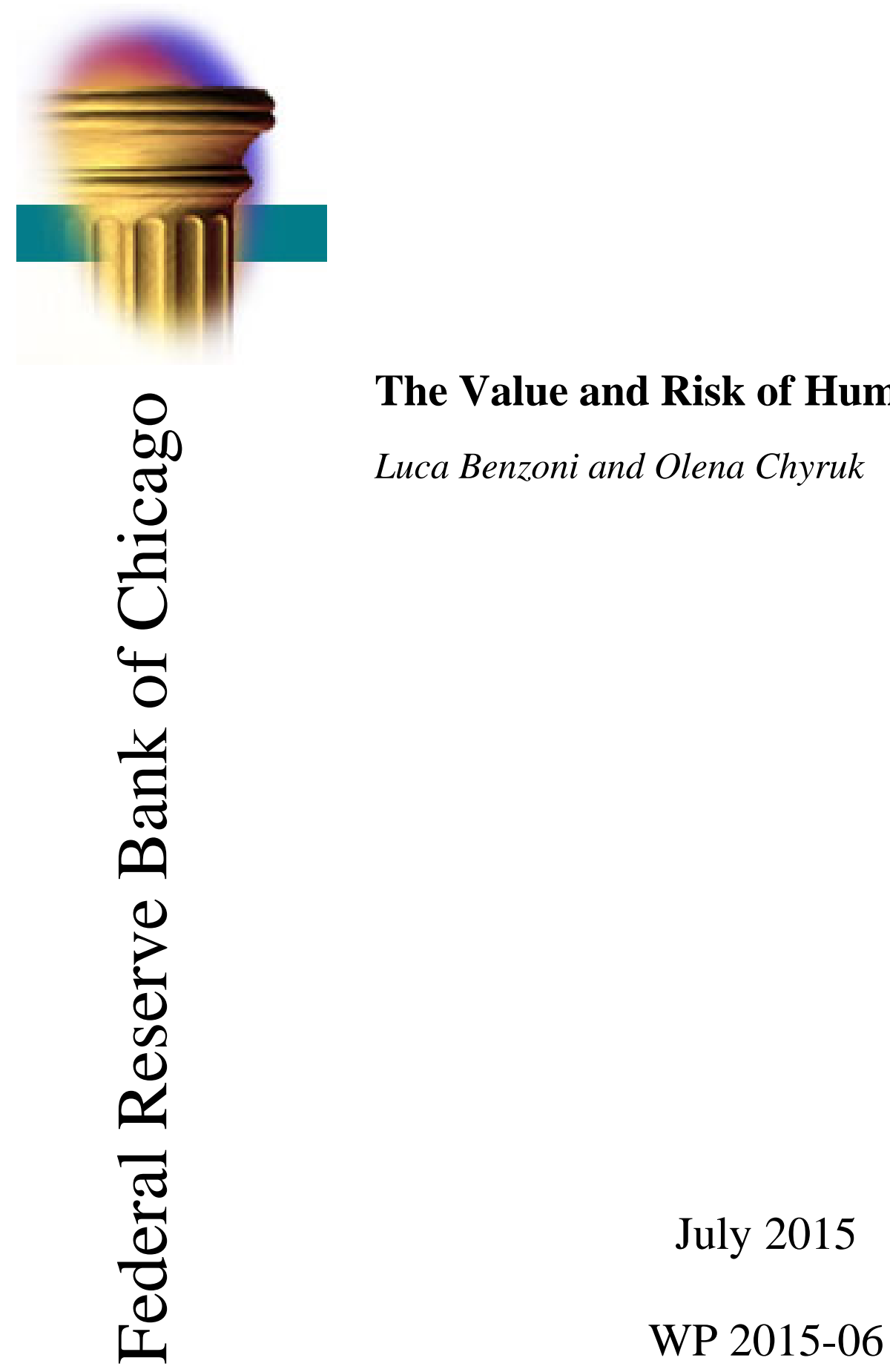


\title{
The Value and Risk of Human Capital ${ }^{*}$
}

\author{
Luca Benzoni ${ }^{\dagger}$ and Olena Chyruk ${ }^{\ddagger}$
}

July 20, 2015

\begin{abstract}
Human capital embodies the knowledge, skills, health, and values that contribute to making people productive. These qualities, however, are hard to measure, and quantitative studies of human capital are typically based on the valuation of the lifetime income that a person generates in the labor market. This article surveys the theoretical and empirical literature that models a worker's life-cycle earnings and identifies appropriate discount rates to translate those cash flows into a certainty equivalent of wealth. The chapter begins with an overview of a stylized model of human capital valuation with exogenous labor income. We then discuss extensions to this framework that study the underlying economic sources of labor income shocks, the choices, such as work, leisure, retirement, and investment in education, that people make over their life, and their implications for human capital valuation and risk.
\end{abstract}

\section{Introduction}

We think of human capital broadly as the set of knowledge, skills, health, and values that contribute to making people productive (e.g., Becker 1964). In a free society, any contract written against future labor services is not strictly enforceable, and ownership of human capital is restricted to the person who embodies it, i.e., labor income is a non-traded asset. Hence, any quantitative analysis of human capital is typically based on the valuation of the income flow that a person generates by 'renting' services in the labor market. While intuitive, this definition is hardly operational without sufficient knowledge of the worker's earnings over the life cycle and appropriate discount rates to translate those cash flows into a certainty equivalent of wealth.

Modeling a worker's life-time earnings is challenging. Heterogeneity in ability and preference for leisure results in cross-sectional income dispersion. Moreover, people adjust their

${ }^{*}$ We are grateful to Dan Aaronson, Gadi Barlevy, Marco Bassetto, Cristina De Nardi, Eric French, Bob Goldstein, Debbie Lucas, Bhash Mazumder, and Anna Paulson for helpful comments and suggestions. Helen Koshy and Vidur Snood provided excellent editorial assistance. The views expressed herein are those of the authors and not necessarily those of the Federal Reserve Bank of Chicago or the Federal Reserve System.

${ }^{\dagger}$ Federal Reserve Bank of Chicago, 230 S. LaSalle St., Chicago, Il 60604, 312-322-8499, lbenzoni@frbchi.org.

${ }^{\ddagger}$ Federal Reserve Bank of Chicago, 230 S. LaSalle St., Chicago, Il 60604, ochyruk@frbchi.org. 
labor supply and the amount of effort exerted at work to buffer wealth, health, and labor income shocks. Further, a worker can choose his retirement date to optimally smooth consumption. Finally, career choices and human capital investment in the form of education have a significant impact on life-time earnings. Due to the complexity of a structural model of labor income that accommodates all these features, researchers often focus on a reducedform specification to estimate the distribution of life-time earnings. They then rely on this statistical model to determine labor income flows in the valuation of human capital.

Identifying a discount rate for the valuation of human capital also presents a challenge. The appropriate rate should reflect the riskiness of workers' labor income flows, which are subject to unexpected fluctuations. Some of these fluctuations are linked to changes in general economic conditions. For instance, wages and employment rates are typically lower when the economy does poorly, especially during a long recession. Similarly, some health problems could increase in the population during an extended economic downturn and contribute to lower aggregate earnings. ${ }^{\text {" }}$ However, labor income also contains a significant idiosyncratic component. For example, many health shocks that are unrelated to aggregate economic conditions could force a person out of the labor force. Similarly, individual productivity shocks could affect a worker's earnings regardless of the overall state of the economy.

In a perfect market, workers could fully insure earnings against shocks by trading explicit claims written against future labor income flows. In practice, market imperfections such as moral hazard, adverse selection, transaction costs, and legal restrictions preclude trading such claims. Self-insurance via precautionary savings and government-sponsored programs (e.g., unemployment insurance and Medicaid in the U.S.) help workers to smooth consumption. Moreover, traded assets like stocks, bonds, and real estate fluctuate with general economic conditions and therefore provide a partial hedge against labor income shocks. Yet, workers remain exposed to idiosyncratic shocks that are not spanned by traded assets. Since such shocks cannot be hedged, the appropriate rate at which to discount future earnings depends on the workers' preferences.

In this article, we discuss how the recent literature has tackled these issues. The chapter begins with a stylized life-cycle model of consumption-saving decisions in which labor income is exogenous. Section $\nabla$ lays out a widely-used statistical model that explains lifecycle earnings in terms of three main components: a deterministic function of individual characteristics, persistent shocks, and transient shocks. We then review the studies that explore the empirical properties of these three components. Next, we derive a rate at which a utility-maximizing worker discounts future earnings flows to determine the value of human capital. The section ends with a synthesis of the financial economics literature that uses this setup to study the value and risk of human capital.

Section 3 extends the framework along several dimensions. First, we review literature that explicitly models work/leisure and retirement decisions rather than treating labor income as

\footnotetext{
${ }^{1}$ See, e.g., The Economist for a non-technical overviews of the literature that studies the linkage between economic downturns and health outcomes: "Body of research: The impact of downturns on physical and mental health," August 24, 2013.
} 
an exogenous process. Second, we discuss human capital investment in the form of schooling, training, and early childhood education. We review theory and evidence with an emphasis on the role of education and credit constraints in explaining heterogeneity in earnings and, therefore, in human capital valuation. Third, we explore various sources of risk that are underlying persistent and transient earnings shocks. Examples of such risks include shocks to individual productivity, health shocks, job arrival shocks, and firm-level shocks that may lead to job creation or destruction. Fourth, we provide an analysis of the linkage between labor income shocks and aggregate economic fluctuations and discuss the implications of time-varying correlations between earnings and stock returns for the value and risk of human

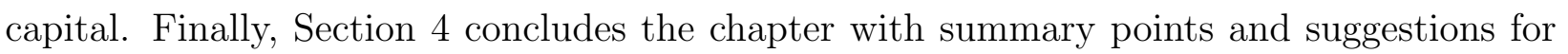
future work.

\section{A Model of Human Capital Valuation}

Valuing human capital involves the pricing of non-tradable future cash flows that a worker will earn in the labor market. Such an exercise requires two basic ingredients: a model for the worker's earnings over the life cycle and an appropriate rate at which to discount those cash flows. Section [.] outlines a standard model for the worker's labor income and surveys the studies that provide empirical support for it. Section 22 presents a stylized life-cycle model of consumption and savings decisions that determines a discount rate for human capital valuation. In Section 2.3 we provide an overview of the financial economics literature that combines these two ingredients to study the value of human capital.

\subsection{A Statistical Model of Labor Income}

For simplicity, here we follow much of the literature in assuming that the labor income process is exogenous. That is, we ignore workers' ability to adjust their labor supply, to optimally choose a retirement date, and to invest in their human capital by pursuing more years of education. While these considerations are important, the assumption that labor income is exogenous is a reasonable starting point as long as the earnings profiles of the model used for human capital valuation closely match the outcomes of workers' decisions reflected in labor income data. We will return to these issues in the second part of the article.

The labor income model of MaCurdy (1982) and Abowd and Card (1989) has become a standard tool in the literature on life-cycle consumption and investment decisions (e.g., Carroll and Samwick (1997), Campbell et al. (2001), Gourinchas and Parker (2002), Cocco, Gomes, and Maenhout (2005), Brown, Fang, and Gomes (2013)). It assumes that the worker $i$ 's age- $t$ labor income, $Y_{i, t}$, is the sum of deterministic and stochastic components,

$$
\log \left(Y_{i, t}\right)=f\left(t, Z_{i, t}\right)+\nu_{i, t}+\varepsilon_{i, t}, \quad t \leq K,
$$

where $K$ is the last year before worker $i$ retires.

The first term, $f\left(t, Z_{i, t}\right)$, is a deterministic function of age $t$ and other individual characteristics $Z_{i, t}$. Empirical evidence suggests that a third-order polynomial in age provides 
a good fit for age effects (e.g., Cocco, Gomes, and Maenhout (2005), Brown, Fang, and Gomes (2013)). Estimation on household-level or individual labor income data delivers a hump-shaped life-cycle earnings profile, consistent with stylized facts on income dynamics (e.g., Attanasio (1995), Hubbard, Skinner, and Zeldes (1995), and Gourinchas and Parker (2002)). Other individual characteristics $Z_{i, t}$ help to explain the life-cycle profile of earnings. For instance, higher levels of education are typically associated with higher lifetime earnings. Other covariates considered in the literature are gender, marital status, household size, and other demographic variables (e.g., Hubbard, Skinner, and Zeldes (1995), Cocco, Gomes, and Maenhout (2005), Guvenen (2009), Brown, Fang, and Gomes (2013)).

The next two terms in equation $(\mathbb{D})$ capture idiosyncratic shocks. The labor income literature distinguishes between persistent shocks, denoted here by $\nu_{i, t}$, and transient shocks $\varepsilon_{i, t}$. It is common to posit that $\nu_{i, t}$ follows a first-order autoregressive process,

$$
\nu_{i, t}=\phi \nu_{i, t-1}+u_{i, t},
$$

where $u_{i, t}$ is a Gaussian i.i.d. mean-zero error uncorrelated across households with constant variance $\sigma_{u}^{2}$. As for the transient shocks, the literature assumes that the $\varepsilon_{i, t}$ process is uncorrelated across households and independent over time with identical Gaussian distribution and constant variance $\sigma_{\varepsilon}^{2}$.

Much effort has gone into determining the persistence of the $\nu_{i, t}$ process. Early work has estimated $\nu_{i, t}$ to have only modest persistence and has attributed most of the observed cross-sectional variation in earnings to heterogeneity in the deterministic component of labor income profiles (e.g., Lillard and Weiss (1979), Hause (1980)). More recently, several studies have revisited this question and have estimated the autoregressive coefficient $\phi$ to be close to one (e.g., MaCurdy (1982), Abowd and Card (1989), Hubbard, Skinner, and Zeldes (1995), Storesletten, Telmer, and Yaron (2004), and Guvenen (2009)). This evidence has motivated several authors to assume that the $\nu_{i, t}$ shocks are permanent. For instance, Carrol (1997), Carroll and Samwick (1997), Campbell et al. (2001), Gourinchas and Parker (2002), Cocco, Gomes, and Maenhout (2005), and Brown, Fang, and Gomes (2013)) assume that $\nu_{i, t}$ follows a random walk, $\phi=1$.

Carroll and Samwick (1997) develop a method for decomposing innovations into transitory and permanent components. Using Panel Study of Income Dynamics (PSID) data from 1981 to 1987 , they estimate the variance $\sigma_{\varepsilon}^{2}$ of the transient component to be approximately twice as large as the variance of the permanent shocks $\sigma_{u}^{2}$. They go on to document wide heterogeneity in their estimates across workers' characteristics, such as education, occupation, and age. For instance, they find an inverse-U pattern in permanent shocks as a function of education: Their $\sigma_{u}^{2}$ estimates increase till workers reach a high-school degree, and they progressively decline for workers who have a higher level of education. In contrast, they find a U-shaped pattern in transitory shocks $\sigma_{\varepsilon}^{2}$ as a function of education. Further, they show a mild U-shaped pattern of both $\sigma_{u}^{2}$ and $\sigma_{\varepsilon}^{2}$ in age.

Several studies after Carroll and Samwick (1997) have followed a similar approach to investigate the properties of labor income risk. Differences in data sources, sample periods, labor income measures, and model specification make it difficult to directly compare their 
findings. This might explain why the conclusions of this body of research are often conflicting. For example, Hubbard, Skinner, and Zeldes (1994) estimate lower $\sigma_{u}^{2}$ and $\sigma_{\varepsilon}^{2}$ coefficients for more educated workers. Campbell et al. (2001) document an increasing pattern in permanent shocks as a function of education and a decreasing relation for transitory shocks. Finally, Meghir and Pistaferri (2004) and Brown, Fang, and Gomes (2013) show a U-shaped pattern for permanent shocks, while transitory shocks are decreasing in education.

In this model, workers retire at a fixed age $K$. From that moment, they receive retirement income that may come in different forms. In the U.S., Social Security is the primary source of retirement income for the majority of retirees; benefits are calculated based on a worker's average indexed monthly earnings during the 35 years of highest earnings. While defined benefit pension plans are becoming less common, there is still a significant portion of the U.S. population that is entitled to such benefits through their former employer; also in this case, benefits are typically computed as a fraction of income earned during the last few years prior to retirement. Alternative pension plans (e.g., defined contribution $401 \mathrm{~K}$ and thrift plans) are also funded by workers by setting aside a fraction of their annual income. Hence, it is reasonable to model retirement income as a constant fraction $\lambda\left(Z_{i, K}\right)$ of permanent labor income in the last working year $K$, where $\lambda\left(Z_{i, K}\right)$ is a function of individual characteristics $Z_{i, K}$ :

$$
\log \left(Y_{i, t}\right)=\log \left(\lambda\left(Z_{i, K}\right)\right)+f\left(t, Z_{i, K}\right)+\nu_{i, K}, \quad t>K .
$$

Among others, Cocco, Gomes, and Maenhout (2005), and Brown, Fang, and Gomes (2013) follow this approach in their empirical investigation of life-cycle labor income profiles.

\subsection{The Private vs. Market Valuation of Human Capital}

We can think of labor income as the cash flow generated by the worker's human capital. Most people rely on their wages to pay for food, shelter, and other necessities. While human capital is possibly their most valuable asset, market imperfections such as moral hazard, adverse selection, transaction costs, and legal restrictions preclude them from borrowing against it by trading explicit claims to their future earnings.

The same market imperfections prevent people from insuring fully against labor income shocks. Self-insurance via precautionary savings and government-sponsored programs (e.g., unemployment insurance and Medicaid in the U.S.) help workers to smooth consumption. Moreover, traded assets like stocks, bonds, and real estate provide a partial hedge for labor income shocks. Yet, the worker remains exposed to idiosyncratic shocks that are not spanned by traded assets. Since these shocks cannot be hedged, the discount rate for future labor income flows may differ from the market discount rate.

In general, the implicit value of a non-traded asset is specific to a person and depends on individual preferences. Only when the cash flows from the non-traded asset are spanned by traded assets, i.e., the market is complete, would the value of the non-traded asset be independent of preferences (e.g., Svensson and Werner (1993), He and Pearson (1991)).

To illustrate the private valuation of human capital, it is useful to start from the life-cycle consumption-savings problem of a person who does not earn labor income. We then consider 
the hypothetical scenario in which the person can trade a claim to future labor income flows, and we determine the shadow price at which he is willing to hold that claim based on his preferences (e.g., Svensson and Werner (1993)).

A person $i$ with time-separable utility is endowed with positive initial wealth $W_{i, 0}$ and lives for $T$ years. He begins the year with wealth from the previous year plus accumulated interest, $W_{i, t-1}(1+r)$, where $r$ is a constant rate of return on invested wealth. Each year he consumes $C_{i, t}$ to maximize the utility function

$$
\mathrm{E}_{1}\left[\sum_{t=1}^{T} \beta^{t-1} U\left(C_{i, t}\right)\right],
$$

where $\beta$ is an intertemporal discount factor, subject to the budget constraint

$$
C_{i, t}=(1+r) W_{i, t-1}-W_{i, t}
$$

Further, we assume that the worker has no access to borrowing, i.e., for each year $t, W_{i, t} \geq 0$.

Suppose now that the same person is allowed to trade a hypothetical asset that generates the labor income flow $Y_{i, t}$ with dynamics in equations (四)-(国). The implicit value of human capital is then the price $V_{i}$ at which he would hold that asset if it were traded on the market. Denote with $\theta$ the amount of the human capital asset the person chooses to buy subject to the augmented budget constraint

$$
\begin{array}{ll}
C_{i, t}=(1+r) W_{i, t-1}-W_{i, t}+\theta Y_{i, t}-\theta V_{i} & \text { for } t=1, \\
C_{i, t}=(1+r) W_{i, t-1}-W_{i, t}+\theta Y_{i, t} & \text { for } 1<t \leq T .
\end{array}
$$

In equation (四), $\theta V_{i}$ denotes the time-1 cost incurred to 'acquire' the human capital asset, while $\theta Y_{i, t}$ denotes the time- $t$ cash flow associated with that claim. The person will then choose $\theta$ and his consumption flow $C_{i}$ to maximize intertemporal utility. The first-order condition of the utility function (甘) with respect to $\theta$ yields

$$
\begin{aligned}
0 & =\mathrm{E}_{1}\left[\sum_{t=1}^{T} \beta^{t-1} U^{\prime}\left(C_{i, t}^{*}\right) \frac{\partial C_{i, t}^{*}}{\partial \theta}\right] \\
& =-U^{\prime}\left(C_{i, 1}^{*}\right) V_{i}+\mathrm{E}_{1}\left[\sum_{t=1}^{T} \beta^{t-1} U^{\prime}\left(C_{i, t}^{*}\right) Y_{i, t}\right]
\end{aligned}
$$

where $C_{i}^{*}$ denotes the optimal consumption plan. Equation (प) yields the standard optimality condition, $U^{\prime}\left(C_{i, 1}^{*}\right) V_{i}=\mathrm{E}_{1}\left[\sum_{t=1}^{T} \beta^{t-1} U^{\prime}\left(C_{i, t}^{*}\right) Y_{i, t}\right]$, which equates the marginal utility cost of acquiring one additional unit of the human capital asset to the marginal benefit of receiving the associated additional labor income cash flows. Rearranging equation ([) gives the implicit value of human capital:

$$
V_{i}=\mathrm{E}_{1}\left[\sum_{t=1}^{T} \beta^{t-1} \frac{U^{\prime}\left(C_{i, t}^{*}\right)}{U^{\prime}\left(C_{i, 1}^{*}\right)} Y_{i, t}\right]
$$




\subsection{The Value and Risk of Human Capital}

The setup of Section $[22$ abstracts from a number of important issues. First, it assumes that people invest their savings exclusively in a safe asset, while in reality they face an array of investment options, e.g., stocks, bonds, and real estate. Second, the life span is fixed at T years, while people face mortality risk. Third, preferences exclude a bequest motive.

Cocco, Gomes, and Maenhout (2005) consider a more general setting that overcomes these limitations. They explicitly model the life-cycle portfolio choice problem of a worker with constant relative risk aversion (CRRA) preferences who splits his financial wealth between a risk-free bond and a portfolio of stocks. Along the way, they account for mortality risk as in, e.g., Hubbard, Skinner, and Zeldes (1994) and introduce a bequest motive in the worker's utility function. The labor income dynamics are similar to equations (四)-(国) with permanent idiosyncratic shocks $(\phi=1$ in equation $(\nabla))$ and coefficients estimated on PSID data. They assume that the worker retires at age 65 and calibrate survival probabilities using the mortality tables of the National Center for Health Statistics. The relative risk aversion coefficient, intertemporal discount rate, risk-free rate, and equity premium are fixed at values commonly found in the literature.

Cocco et al. solve their model numerically and evaluate the implicit value of human capital by discounting labor income flows at the worker's intertemporal marginal rate of substitution (equation ( $(\mathbb{8})$ ). They find the value of human capital to be hump-shaped over the life cycle with a peak around age 35 . That is, although young people face a longer stream of future labor income, they discount such cash flows more than older agents. This occurs for two reasons. First, the predictable labor income component has a hump-shaped profile: Higher labor income cash flows occur at older ages and therefore are subject to greater time discounting. Second, as the worker ages, he faces lower idiosyncratic labor income uncertainty. Consistent with this intuition, Benzoni, Collin-Dufresne, and Goldstein (2007) document that the worker's discount rate associated with the permanent idiosyncratic labor income shocks has a downward-sloping profile.

Brown, Fang, and Gomes (2013) consider a similar setup that abstracts from portfolio choice decisions and focuses instead on the linkage between the worker's education and the value of his human capital. The authors consider three levels of education: workers without a high school diploma, those who have it, and college graduates. They estimate the labor income model on PSID data from 1968 to 2007 on a sample of PSID household heads, who are still in the labor force and aged between 20 (22 if college graduates) and 65. The measure of income includes post-tax labor income, unemployment income, and Social Security benefits. As in equation (B), after retirement workers receive a constant fraction of permanent labor income in the last working year.

For a range of preference parameters, Brown et al. find that the typical high school graduate will enjoy a level of consumption that is $24 \%$ higher than those who did not attend high school. When expressed in terms of life-time certainty equivalent (i.e., risk-adjusted) wealth, this corresponds to an increase of $\$ 220,000$ in 2010 dollars. The gain from college education is larger. The increase in present-value of human capital of the average college 
graduate is $\$ 432,000$, which corresponds to a $38.5 \%$ increase in annual certainty-equivalent consumption. These estimates are smaller than the numbers often found in the popular press. $^{\square}$ Brown et al. attribute the differences to the measure of labor income they use, which is net of income and payroll taxes, and to the risk-adjusted discount rate they apply to value future labor income flows.

Further, differences in risk aversion, unemployment risk, and earnings volatility can produce significant heterogeneity in estimated returns to education. This sets the Brown et al. results apart from the labor economics literature that studies the linkage between education and earnings via linear regressions without giving full consideration to risk (e.g., Card 1999). In particular, Brown et al. estimate a U-shaped pattern in permanent labor income shocks as a function of education. They find that high school graduates face lower idiosyncratic risk than workers without a high school degree and college graduates. Hence, they discount future earnings at a lower rate, which increases the present-value of their human capital. College graduates experience higher expected earnings and lower unemployment risk. However, they also face a much more skewed distribution of lifetime earnings due to, e.g., career earnings heterogeneity. Thus, they discount future earning at a higher rate.

\section{Extensions and Directions for Future Work}

The discussion so far has focused on statistical models that treat labor income as an exogenous process. Here we discuss the literature that extends the analysis to account for work-leisure and retirement decisions, as well as the choice to invest in human capital in the form of education. Further, the framework of Section (四) is silent about the economic sources of risk that underlie shocks to earnings and, thus, cannot be used to disentangle fluctuations in income due to exogenous shocks from those due to the effects of actions (e.g., adjusting hours worked or retirement date) taken by workers in response to such shocks. To shed light on these issues, we review recent studies that explicitly model shocks to individual productivity, health shocks, job arrival shocks, and firm-level shocks that may lead to job creation or destruction, and their role in driving labor income fluctuations. Moreover, we discuss work that explores the link between labor income shocks and aggregate economic fluctuations. Delving more into these issues is important to obtain a more precise estimate of the value of human capital and to better understand the sources of its risk.

\footnotetext{
${ }^{2}$ For instance, the 2011 ["Education and Synthetic Work-Life Earnings Estimates"] report by the U.S. Census estimates that a college degree increases lifetime earnings by around one million dollars compared with lifetime earnings of a worker with a high school diploma.

${ }^{3}$ The conclusions of Brown et al. hinge on their estimate of a U-shaped pattern in the variance of permanent idiosyncratic shocks with respect to education. This pattern, however, is controversial in the literature

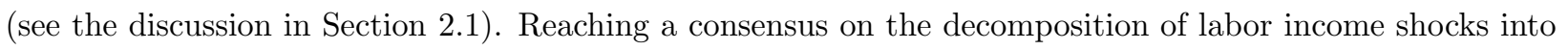
permanent and transitory components remains an important area of work.
} 


\subsection{Models of Labor Supply}

The labor income model in Section [2.] specifies a univariate process of earnings. Thus, its ability to identify the various sources of fluctuations in income is limited. In contrast, recent work in labor economics focuses on multivariate models that include the distinct determinants of earnings. For instance, Altonji et al. (2013) consider specifications that incorporate hours and wages, as well as discrete events such as job changes, employment loss, interactions between job changes and wages, and the effects of these discrete events on the variance of wage and hours shocks.

The framework of Altonji et al. (2013) is very rich. While not structural, their equations can be viewed as approximations to the decision rules relating work and leisure choices to state variables that would arise in a fully specified model of lifetime utility maximization. In this interpretation, the parameters in the Altonji et al. (2013) equations depend on an underlying set of coefficients that describe a worker's preference for leisure, job search technology, and other economic fundamentals.

Human capital valuation, however, requires a discount rate to translate future labor income flows into a certainty equivalent of wealth (equation ( $(\mathbf{8})$ ). To this end, the hours/wages processes estimated by Altonji et al. (2013) could be used in the calibration of a life-cycle model that is more general and flexible than those discussed in Section [2.3. Alternatively, one could pursue the estimation of a structural life-cycle model that includes some of the features of the Altonji et al. (2013) specifications. Recent work by Low, Meghir, and Pistaferri (2010) is a major step in this direction. The authors explore a structural life-cycle model of consumption, labor supply, and job mobility in an economy with search frictions. The fundamental sources of risk in their model include shocks to individual productivity, job arrival shocks when employed and unemployed, and firm-level shocks that lead to job destruction. They go on to quantify empirically such risks in the presence of labor market frictions and conclude that allowing for job mobility has a large effect on the estimate of productivity risk. Exploring the implications of these results for the value and risk of human capital is a promising area of future work. ${ }^{\text {m }}$

\subsection{Human Capital Investment}

The results of Brown, Fang, and Gomes (2013) that we discussed in Section 2.3 show that a great deal of cross-sectional variation in the value of human capital is linked to the worker's education. Brown et al., however, take age-earnings profiles conditional on education as given, rather than focusing on the worker's choice to pursue education over the life cycle. Related, they abstract from other forms of investment in human capital, such as training, early childhood intervention, and medical care.

\footnotetext{
${ }^{4}$ Several studies in the financial economics literature explore life-cycle portfolio choice models with a leisure/labor trade-off and retirement decisions, e.g., Bodie, Merton \& Samuelson (1992), Bodie, Detemple, Otruba, \& Walter (2004), Farhi, Emmanuel \& Panageas (2007). Their focus is on the effect of variable labor supply on stock market holdings.
} 
The idea of human capital investment goes back to the seminal work of Becker (1964). To understand the incentives for such investment and its implications for wages and earnings, it is useful to articulate the uses of human capital in the production process of a firm. For example, Becker (1964) thinks of human capital as the stock of knowledge and skills embodied in a worker and used by the firm as an input. Subsequently, other views have emerged (e.g., Acemoglu and Autor 2013). The first is the Gardener view, named after the proponent of the multi-intelligence theory that distinguishes between, e.g., mental and physical abilities, which attributes similar dimensions to human capital. Acemoglu and Autor dub the second as the Schultz/Nelson-Phelps view, which thinks of human capital as the capacity to adapt to a changing environment. Third, the Bowles-Gintis view identifies human capital with the ability to follow directions and work in hierarchical organizations. While these previous interpretations are similar in many respects, the fourth one, which Acemoglu and Autor call the Spence view, stands out as it considers observable measures of human capital (e.g., education) as a signal of ability rather than a useful production factor.

Alternative interpretations of the uses of human capital imply different investment incentives. For instance, in the Spence view a costly investment in education is worthwhile if it allows a high-ability worker to signal his type to an imperfectly informed employer; while in the Becker view education produces knowledge that directly increases a person's productivity. More broadly, this distinction determines the way we think of the different components of human capital. These include innate ability, schooling and training, and other factors such as school quality, environment, and peer effects.

\subsubsection{Schooling and Training}

Most of the theoretical work on schooling and training draws on Becker's view that education makes people more productive. The basic idea in this literature is that people with different innate ability face the trade-off between paying for education (in the form of tuition fees and foregone income) to acquire skills that will increase their future productivity and salary. People with higher ability experience a higher return to education (other things being equal) and therefore have a stronger incentive to invest in human capital. With perfect capital markets, workers can finance the cost of schooling and thus obtain their optimal level of education. In the presence of market imperfections such as credit constraints, access to borrowing is limited. This causes constrained individuals to invest less, stopping their schooling when the marginal return is still relatively high (e.g., Lochner and Monge-Navarro 2012).

In addition to attending school, the worker can pursue more education after the beginning of his employment. The seminal contribution of Ben-Porath (1967) includes knowledge depreciation and studies human capital accumulation in the form of post-school training. His model underscores the continuity of the investment in education during and after the school years. He finds that the optimal investment in human capital has a declining pattern that goes to zero as the worker approaches retirement, since at that time the opportunity cost of foregoing wages for more training outweighs the benefit of future productivity gains. These results are consistent with the hump-shaped earnings profile that workers typically 
experience over the life cycle and the hump-shaped profile in human capital.

In contrast to the notion that schooling produces skill, Spence (1973) views education as a signal that high-ability workers use to convey their type to uninformed employers and therefore secure a higher salary. To obtain a separating equilibrium, it is important that high-ability workers face a lower cost to invest in human capital than low-ability people, so that they can attain a level of education that is too costly for the low-ability workers given the salary differential between the two ability types. However, pooling equilibria are also possible, though they can often be ruled out by appropriately restricting the concept of equilibrium (e.g., Cho and Kreps 1987).

There is a positive correlation between the education level of a worker and his earnings. However, labor economists have been careful about drawing the conclusion that more education causes higher earnings. First, the most productive workers are those who also have the strongest incentive to pursue more years of education, i.e., there could be an ability bias. This is consistent with Becker's view of human capital theory, where more able workers benefit more from longer schooling. But it is also consistent with Spence's view, where workers use education as a signal. Second, there could be a selection bias, as people tend to study fields in which they are most efficient and motivated. A vast literature deals with these biases by studying the linkage between earnings and education in a sample of identical twins. Based on the evidence of these studies, Card (1999) concludes that the ability bias is rather small.

The findings of this empirical literature suggest that one additional year of schooling yields a 6-15\% increase in a worker's annual salary (e.g., Card 1999). This evidence is consistent with Becker's view that education makes workers more productive. Testing Spence's signaling view is more challenging. In both Becker's and Spence's views, part of the difference in earnings between high- and low-education workers is due to differences in ability. However, in Becker's theory ability may be unobserved by the econometrician but it is known to the employer; while in the signaling theory it is unobserved by employers, as well as by the econometrician. Acemoglu and Autor (2011) review empirical studies that attempt to gauge the signaling return to education. Overall, there is some evidence for the signaling channel, although the strength of the effect is hard to quantify.

The evidence of credit constraints on schooling decisions is also mixed. The comprehensive survey article by Lochner and Monge-Navarro (2012) concludes that borrowing constraints had little effect on college attendance in the early 1980s. Since then, in the U.S.,

\footnotetext{
${ }^{5}$ Other research has relied on instrumental variable (IV) regressions based on institutional changes in the education system to establish a causal link between education and earnings. Card summarizes the evidence in this literature and reports that the estimated returns to schooling via IV regressions are $20-40 \%$ above the corresponding ordinary least squares estimates. Card's interpretation of this evidence is that the marginal returns to schooling for certain subgroups of the population-particularly those whose schooling decisions are most affected by structural innovations in the school system - are somewhat higher than the average marginal returns to education in the population as a whole.

${ }^{6}$ While these estimates imply that education significantly raises future earnings, it is worth underscoring that the $R^{2}$ of these regression is typically small, which suggests that there are determinants other than years of schooling that explain variation in earnings.
} 
both college attendance and tuition have risen, much faster than credit limits of governmentsponsored student loan programs. For instance, Lochner and Monge-Navarro (2012) report that $26 \%$ of all dependent undergraduate students at four-year public universities in the United States were borrowing the maximum allowable amount from the Stafford Loan Program in 1999-2000, compared with fewer than $4 \%$ of students ten years earlier. The private sector has stepped in to meet, at least partly, the increasing credit demand. Lochner and Monge-Navarro note that private student credit increased rapidly from virtually zero in the early 1990s to $9 \%$ of all student loan dollars distributed in 1999-2000. Taken together, this evidence suggests that, in recent years, credit constraints have become more important for higher education decisions in the United States. These constraints could impact not only educational attainment, but also college quality, work/consumption decisions while in school, and saving/investment decisions (e.g., Palacios-Huerta 2003, Saks \& Shore 2005, Roussanov 2010, Athreya et al. 2013). Finally, extending credit for human capital requires repayment enforceability and raises other incentive problems (e.g., Lochner and Monge-Navarro 2011).

\subsubsection{Early Childhood Investment}

While there is extensive work on the returns to school and college education investment, only recently has the human capital literature started to focus on the long-term effects of early childhood education (e.g., Almond \& Currie 2011 and Cunha et al. 2006). This research finds that early childhood intervention among children with disadvantaged background leads to higher test scores, decreased grade retention, decreased time in special education, decreased crime and delinquency, and increased high school graduation rates. This new wave of work stresses the need for a better understanding of the life-cycle skill formation process. It differentiates between early and late investments in human capital. Moreover, it recognizes the roles of both cognitive and noncognitive (e.g., perseverance, self-control, reliability, consistency, motivation, and optimism) abilities in determining the returns to human capital (Cunha \& Heckman 2008, Cunha \& Heckman 2010, and Cunha et al. 2010). In this setup, the skill production technology exhibits dynamic complementarity (early investments increase the productivity of later investments) and self-productivity (the skills acquired in the early stage augment the skills acquired in later periods). These two features produce multiplier effects as skills acquired today beget more skills in the future. According to this literature, effective public policies would focus on young children's human capital investments as they have the highest return compared with investments in later years. Moreover, such policies may potentially reduce lifetime inequality as differences in early life conditions have been found to explain a significant portion of the variation in lifetime earnings and wealth (Huggett et al. 2006, 2011).

Yet, some low-income families do not make the same investment in early childhood programs as higher-income households do. One possible explanation is the presence of borrowing constraints. Indeed, an increase in family income at early childhood ages has a greater effect on educational achievement than income received at later ages (e.g., Dahl \& Lochner 2012). This finding is consistent with the dynamic complementarities discussed above: Higher early 
investment leads to higher returns for later investments in education, while it is difficult to amend inadequate levels of early investments with higher investments later in life (Keane \& Wolpin 2001, Cameron \& Heckman 1998). In an overlapping generation model of human capital production, Caucutt \& Lochner (2012) show that relaxing credit constraints on young parents would increase both early investments in young children and late investments in older children. In contrast, a policy that focuses on subsidizing college education alone might not be as effective in increasing human capital investment. The effect on future generations, however, is more ambiguous. Increased borrowing causes higher debt levels that result in parents transferring less resources to their children in the long run. This in turn could limit the ability of future generations to sustain the same increased level of human capital investment.

This discussion underscores that the timing of human capital investment over the life cycle is important. Early childhood investment is critical, but it is highly illiquid and requires significant time and financial costs. Lochner and Monge-Navarro (2012) argue that the constraints faced by parents when investing in early childhood education are more pervasive and harmful than the constraints people face at college ages. The findings of this literature provide support for public policies that facilitate access to early childhood education, especially for underprivileged households. For instance, Restuccia and Urrutia (2004) conclude that social programs that help finance early education have a larger impact on earnings mobility than an increase in college subsidies.

\subsection{Health Shocks}

Individual health has a broad effect on most lifetime labor market outcomes, including wages, earnings, labor force participation, hours worked, and retirement. As such, the literature views health as one of the human capital components (e.g., Becker 1964). While it is intuitive that a large negative health shock can lead to a decline in lifetime earnings, numerous empirical studies have struggled to gauge the magnitude of these changes.

In their survey, Currie \& Madrian (1999) discuss three main issues that are important to disentangle the effect of health status on labor market outcomes. First, it is difficult to measure health shocks. Thus, the estimates differ based on measures of health being used (e.g., mental health, heart diseases, external accidents). Second, there is a vast crossdisciplinary literature that argues that individual socioeconomic status (e.g., education and wealth) determines the investment in a person's health and, thus, health capital (e.g., Smith 1999). Third, since health and labor market outcomes are endogenous variables, estimates of the effect of a health shock on wages, and vice versa, are sensitive to the identification assumptions (e.g., Lee 1982, Haveman et al. 1994, Riphahn 1999, Au et al. 2005, Disney et al. 2006).

In general, these studies focus on the adult population to determine the relationship between health and labor market activity. But there is also growing evidence that the early childhood environment significantly influences later life outcomes. Almond \& Currie (2011) provide an extensive summary of recent work. The main finding of this literature is that 
shocks before the age of five years lead to significant long-term consequences. In particular, poor health in childhood affects both adult health status and investments in other forms of human capital (such as education). And even a compromised prenatal environment can have long-term negative effects on future health outcomes (e.g., Almond \& Mazumder 2011, Barker \& Osmond 1986, Kraemer 2000). Furthermore, there is evidence that poor health in childhood is associated with reduced educational attainment as well as lower wages and labor force participation (e.g., Grossman 1975, Perri 1984, Wolfe 1985, Wadsworth 1986, and Smith 2009).

This discussion suggests that health shocks could have a significant impact on lifetime earnings. Moreover, the dynamics of health and health insurance coverage (e.g., De Nardi et al. 2013) affect the price of health care relative to non-health consumption and, therefore, the rate at which workers discount future labor income flows. Yogo (2007) builds on these ideas with a life-cycle model in which a retiree faces stochastic health depreciation, which affects his marginal utility of consumption and his life expectancy. The retiree receives income (including Social Security) and chooses consumption, health expenditure, and the allocation of wealth among bonds, stocks, and housing to maximize lifetime utility. Yogo's focus is on explaining the cross-sectional variation and the joint dynamics of health expenditure, health, and wealth for retired workers. ${ }^{\square}$ Extending his work to the life-cycle problem of a young worker is a promising step toward a better understanding of the value and risk of human capital in the presence of health shocks.

\subsection{Aggregate vs. Idiosyncratic Labor Income Shocks}

Extended periods of strong economic activity are likely to be associated with sustained earnings growth, and vice versa. Hence, it is natural to conjecture the presence of dependence between labor income shocks and aggregate economic fluctuations. Here we review the literature that studies different channels through which economic shocks might propagate into a worker's earnings and discuss the implications for the value and risk of human capital. We focus in particular on articles that use stock market performance as a proxy for economic conditions and explore short- vs. long-run correlations between stock returns and earnings.

\subsubsection{Contemporaneous Correlation}

Campbell et al. (2001), Cocco, Comes, and Maenhout (2005), Gomes and Michaelides (2005), and Viceira (2001) explore the effect of contemporaneous correlation between labor income and stock market innovations. They assume that logarithmic labor income is the sum of a deterministic component, permanent idiosyncratic shocks $\nu_{i}$ and transient shocks $\varepsilon_{i}$ - similar to equations (四)-(四) but with random walk dynamics for $\nu_{i}$ :

$$
\nu_{i, t}=\nu_{i, t-1}+u_{i, t}
$$

\footnotetext{
${ }^{7}$ French (2005), French \& Jones (2011), and van der Klaauw \& Wolpin (2008) study the interaction between retirement decision and uncertain health status.
} 
These authors decompose the permanent shock $u_{i, t}$ into an aggregate component $\xi_{t}$ distributed as $N\left(0, \sigma_{\xi}^{2}\right)$ and an idiosyncratic component $\omega_{i, t}$ distributed as $N\left(0, \sigma_{\omega}^{2}\right)$ :

$$
u_{i, t}=\xi_{t}+\omega_{i, t}
$$

They then introduce the stock market portfolio $S$ with total return

$$
r_{t}=\log S_{t}-\log S_{t-1}=\mu_{s}+\eta_{t}
$$

where $\eta_{t}$ denotes $N\left(0, \sigma_{\eta}^{2}\right)$ innovations that are independently and identically distributed over time.

This framework allows for contemporaneous correlations between stock market shocks $\eta_{t}$ and aggregate labor income shocks $\xi_{t}$. Empirical support for this channel, however, is limited. Early work by Davis and Willen (2000) obtains estimates for the coefficient $\rho=\operatorname{corr}\left(\eta_{t}, \xi_{t}\right)$ that range from 0.1 to 0.3 for college-educated males and -0.25 for male high school dropouts. More recently, Cocco, Gomes, and Maenhout (2005) estimate $\rho$ to be nearly zero, i.e., they do not find a significant contemporaneous correlation between stock market returns and permanent labor income shocks. Campbell et al. (2001) also find extremely low and insignificant contemporaneous correlations across households with different levels of education; their estimates are higher only when computed on excess stock returns lagged one year. Entrepreneurial risk, however, correlates more highly with stock market risk; for instance, Heaton and Lucas (2000) find that the correlation between the quarterly growth rate of real nonfarm proprietary income (as reported in the NIPA) and the CRSP valueweighted return is 0.14 , whereas the correlation between the value-weighted return and the quarterly growth rate of real aggregate wages is -0.07 .

\subsubsection{Countercyclical Volatility of Idiosyncratic Shocks}

Storesletten et al. (2004) consider a model with persistent idiosyncratic shocks $u_{i, t}$ (as in equation (घ)) with variance $\sigma_{u, t}^{2}$ that is common across agents and varies over the business cycle:

$$
\sigma_{u, t}^{2}= \begin{cases}\sigma_{u_{E}}^{2}, & \text { if aggregate expansion at date } t \\ \sigma_{u_{C}}^{2}, & \text { if aggregate contraction at date } t .\end{cases}
$$

They estimate the model on PSID data from 1968 to 1993 via the generalized method of moments (GMM). They find idiosyncratic risk to be (i) highly persistent, with an annual autocorrelation coefficient $\phi=0.95$, and (ii) strongly countercyclical, with a conditional standard deviation that increases by $75 \%$ (from $\sigma_{u_{E}}^{2}=0.12$ in an expansion to $\sigma_{u_{C}}^{2}=0.21$ in a contraction) as the macroeconomy moves from peak to trough. Their estimates translate into contraction/expansion conditional standard deviations of $\$ 9,500$ and $\$ 5,300$, based on the average worker's 2002 dollar earnings of $\$ 45,000$. These computations are useful to gauge the impact of idiosyncratic risk on a person's earnings and how the shocks vary over the business cycle. 


\subsubsection{Procyclical Mean of Labor Income Growth}

Lynch \& Tan (2008) extend the Storesletten et al. (2004) framework to allow for fluctuations in the conditional mean of the labor income flow at business cycle frequencies. They use the dividend yield $D$ on a stock market portfolio as a proxy for the business cycle and assume that $d_{t}=\log \left(1+D_{t}\right)$ follows a mean-reverting process:

$$
d_{t}=\mu_{d}+b_{d} d_{t-1}+\varepsilon_{t}
$$

where $\varepsilon_{t}$ denotes a $N\left(0, \sigma_{\varepsilon}^{2}\right)$ i.i.d. shock. In their model, the conditional mean of both stock market return and the permanent component of labor income is a linear function of the $d_{t}$ predictor:

$$
\begin{aligned}
r_{t} & =\mu_{s}+b_{s} d_{t}+\eta_{t} \\
\nu_{i, t} & =\nu_{i, t-1}+\mu_{\nu}+b_{\nu} d_{t}+u_{i, t},
\end{aligned}
$$

where $\eta_{t}$ and $u_{i, t}$ are mean-zero Gaussian i.i.d. innovations with variances $\sigma_{\eta}^{2}$ and $\sigma_{u}^{2}$, respectively.

Using data on retail trade income growth and the 12-month dividend yield on the valueweighted NYSE index, they estimate $b_{\nu}<0, b_{s}>0$, and $b_{d}$ close to one. That is, they find the permanent component of labor income to be procyclical, while the dividend yield is countercyclical. Further, they find countercyclical fluctuations in the volatility of idiosyncratic shocks similar to Storesletten et al. (2004).

\subsubsection{Cointegration Between Labor Income and Stock Market Returns}

Several studies explore the effect of long-run co-dependence between aggregate economic conditions and labor income. It is straightforward to incorporate this feature into the framework that we review here in the form of cointegration between labor income and stock returns, or labor income and aggregate economic activity (e.g., Campbell 1996, Baxter \& Jermann 1997, Lucas \& Zeldes 2006, Santos \& Veronesi 2006, Benzoni et al. 2007, and Huggett \& Kaplan 2013). To this end, it is convenient to specify the logarithmic labor income process $y_{i, t}=\log \left(Y_{i, t}\right)$ as the sum of aggregate $y^{A}$ and idiosyncratic $y_{i}^{I}$ components,

$$
y_{i}=y^{A}+y_{i}^{I} .
$$

Similar to equation $(\mathbb{\square})$, the idiosyncratic labor income component contains deterministic and stochastic terms,

$$
y_{i}^{I}=f\left(t, Z_{i, t}\right)+\nu_{i, t}^{I}+\varepsilon_{i, t} .
$$

As in, e.g., Cocco, Gomes, and Maenhout (2005), the $\nu_{i, t}^{I}$ process follows a random walk with i.i.d. error $\omega_{i, t}$,

$$
\nu_{i, t}^{I}=\nu_{i, t-1}^{I}+\omega_{i, t},
$$

while $\varepsilon_{i, t}$ is a transient i.i.d. shock.

To capture deviations between aggregate labor income and stock market values, we introduce a variable $h=y^{A}-s$, where $s=\log (S)$ is the logarithmic price of the stock market 
portfolio with return $r_{t}=\Delta s_{t}$ given in equation (ㅁ). While there may be short-run deviations between aggregate earnings and stock market values, it is natural to conjecture that a sustained period of high economic growth will result in strong stock and labor market performance, so that these two markets will move together in the long run. To generate this type of co-movement in the model, we assume that $y^{A}$ and $s$ are cointegrated with a time trend, i.e., $h$ is trend-stationary with dynamics ${ }^{\mathbf{8}}$

$$
\Delta h_{t}=\kappa\left(\theta t-h_{t}\right)+z_{t}-\sigma_{h_{\eta}} \eta_{t}
$$

where $z_{t}$ is a $N\left(0, \sigma_{z}^{2}\right)$ i.i.d. shock that is independent of the stock market innovation $\eta_{t}$. The coefficient $\kappa$ measures the speed of mean reversion for the cointegration relation. In particular, $\tau=\log (2) / \kappa$ is the half-life of shocks to $h$; larger values of $\kappa$ imply a faster decay toward the long-run trend $\theta t$.

In first differences, the labor income process is

$$
\Delta y_{i, t}=\Delta y_{t}^{A}+\Delta y_{i, t}^{I}
$$

Substituting $\Delta y^{A}=\Delta h+\Delta s$ into equation (미) yields an expression for the total labor income dynamics,

$$
\Delta y_{i, t}=-\kappa h_{t}+\kappa \theta t+\Delta f\left(t, Z_{i, t}\right)+\xi_{t}+\omega_{i, t}+\Delta \varepsilon_{i, t}
$$

where, as in Cocco, Gomes, and Maenhout (2005), we can interpret $\xi_{t}=z_{t}+\left(1-\sigma_{h_{\eta}}\right) \eta_{t}$ as a Gaussian i.i.d. shock to the aggregate component of labor income with mean zero and variance $\sigma_{\xi}^{2}=\sigma_{z}^{2}+\left(1-\sigma_{h_{\eta}}\right)^{2} \sigma_{\eta}^{2}$.

The model of Cocco, Gomes, and Maenhout (2005) is a special case of this framework. In the limit when the mean reversion parameter $\kappa \rightarrow 0$, equation (미) collapses into the expression for their labor income process in first differences. As in Cocco, Gomes, and Maenhout (2005), the labor income model described by equation (지) allows for contemporaneous correlation between labor income and stock market shocks,

$$
\operatorname{corr}\left(\xi_{t}, \eta_{t}\right)=\frac{\left(1-\sigma_{h_{\eta}}\right) \sigma_{\eta}}{\sqrt{\sigma_{z}^{2}+\left(1-\sigma_{h_{\eta}}\right)^{2} \sigma_{\eta}^{2}}} .
$$

This correlation can be set equal to the value of the $\rho$ correlation coefficient estimated by, e.g., Cocco, Gomes, and Maenhout (2005) with an appropriate choice of $\sigma_{h_{\eta}}$. However, this framework also allows for non-zero long-run correlations between labor income and stock market returns that can be large even if the contemporaneous correlation is small. In particular, when $\sigma_{h_{\eta}}=1$, the contemporaneous correlation in equation (四) is zero, yet the long-run correlations driven by the cointegrating variable $h$ are positive when $\kappa>0$.

\footnotetext{
${ }^{8}$ The model in equation (षㅣ) is mathematically equivalent to an alternative specification with $h=y^{A}-d-$ $\overline{y^{A} d}$, where $d$ is the logarithmic dividend process, $\overline{y^{A} d}$ is the long-run log-ratio of aggregate labor income to dividends, and $h$ is a stationary mean-reverting process without time trend (e.g., Benzoni, Collin-Dufresne, and Goldstein 2007).
} 
Several articles explore a cointegration relation similar to equation (ㅃ). For instance, Baxter and Jermann (1997) study the correlation in returns to human and physical capital using annual data on labor income and capital income for Japan, Germany, the United Kingdom, and the United States over the period 1960-1993. They measure labor income as total employee compensation while capital income is GDP at factor cost minus employee compensation. For each country, they find that domestic human capital returns are strongly correlated with the returns to domestic physical capital. However, they report only weak evidence that labor and physical capital income are cointegrated. Benzoni, Collin-Dufrense, and Goldstein (2007) explore the cointegration relation between labor income and aggregate stock market dividends, while Huggett and Kaplan (2013) focus on labor income and stock market returns. Also in these cases, the evidence for cointegration is limited, with results that are sensitive to the choice of the sample period.

While the empirical evidence in its support is weak, it is nonetheless worthwhile to investigate cointegration between labor income and stock market returns as a possible source of aggregate risk in individual earnings. First, the tests used to reject the null hypothesis of a unit root in equation (ष) are notorious for lacking power. This limitation could well explain the lack of empirical support for cointegration. Second, economic intuition suggests that returns to human and physical capital should be correlated. Third, empirical evidence suggests that the capital and labor income shares fluctuate over time. A model with cointegration accommodates this evidence by allowing for short-term variation in factor shares while retaining the long-run restriction that factor shares are stationary. This is a desirable feature; as Baxter and Jermann (1997) point out, if the labor and capital income were allowed to have independent trends, then the ratio of labor income to capital income would either grow without bound or approach zero asymptotically, and the labor share would approach either zero or one. This seems unlikely and counterfactual.

\subsubsection{Implications for Human Capital Valuation and Risk}

One of the channels through which economic conditions could affect individual labor income is the contemporaneous correlation between aggregate earning shocks and stock market returns, denoted by the coefficient $\rho$ in Section [.4. weak. For instance, Cocco et al. (2005) report estimates of $\rho$ that are close to zero and statistically insignificant. They then go on to solve the life-cycle problem of a worker when the correlation coefficient between labor income and stock market risk is set at their small estimate. Their main conclusion is that in this setting labor income acts as a substitute for risk-free asset holdings, a finding that confirms earlier results obtained by Heaton and Lucas

\footnotetext{
${ }^{9}$ Lustig and Van Nieuwerburgh (2006) reach conclusions at odds with this intuition. They use a representative agent model with recursive utility and observed aggregate consumption to back out consumption innovations that cannot be attributed to news about current or future financial returns. They attribute such innovations to the returns on human wealth and find them to be negatively correlated with shocks to financial asset returns. Their results, however, may be sensitive to model assumptions; for instance, Bansal et al. (2013) argue that extending their model to include stochastic macroeconomic volatility results in a positive correlation between returns to human capital and financial wealth.
} 
(1997) in an infinite-horizon model.

In contrast, several studies find comovements between labor income and stock returns at business cycle frequencies to have a significant effect on the value and risk of human capital. For instance, Storesletten et al. (2007) consider an overlapping generations model in which idiosyncratic labor income risk is subject to countercyclical variation, a feature documented in Storesletten et al. (2004) and discussed in Section B.4.2. In this setting, they show that the distribution of aggregate risk affects portfolio holdings in the economy, giving rise to a hump-shaped risky asset share of financial wealth over the worker's life cycle. This is because, in their model, human capital acquires stock-like features due to the cyclical component in the variance of earnings. For a worker exposed to stock market risk via the implicit stock position embedded in human capital, it is optimal for him to reduce his direct stock holdings, especially when he is young and most of his wealth is tied up in future labor income. Lynch and Tan (2011) confirm the results of Storesletten et al. (2007) and extend them to a model that, in addition to countercyclical idiosyncratic volatility, also features procyclical labor income growth (see the discussion in Section [3.4.3).

Benzoni et el. (2007) obtain similar results in a model that features cointegration between the aggregate component of labor income and dividends. Also in this case, long-run comovements between stock returns and earnings expose workers to market risk and human capital displays a stock-like component, especially when the worker is young. ${ }^{\mathbf{m}}$ Huggett and Kaplan (2013) consider a more general framework that includes all channels of exposure of labor income to aggregate risk, among which they favor countercyclical variation in idiosyncratic labor income risk. They also find a stock component in human capital, though not as large as the one reported in Benzoni et el. (2007).

Overall, the evidence discussed here suggests that labor income risk contains an aggregate component that affects long-run fluctuations in earnings. It is difficult, however, to assess the magnitude of this component with data that span only a few decades. For the same reason, it is hard to disentangle the different channels through which aggregate risk spills into individual labor income. In spite of these challenges, these issues are worth further investigation. These efforts help us to better understand the sources of risk in human capital and to identify a discount rate that accurately reflects the riskiness of future labor income flows. Further, different occupations may expose workers to various degrees of aggregate shocks. This applies to people employed across different industries as well as self-employed workers and entrepreneurs (Heaton and Lucas 2000). Hence, heterogeneity in the exposure to aggregate risk could be an important source of cross sectional variation in human capital valuation.

\footnotetext{
${ }^{10}$ Lucas \& Zeldes (2006) consider a similar model for the valuation and hedging of defined-benefit plans, while Geanakoplos \& Zeldes (2010) study the effect of cointegration between labor income and stock returns on the valuation of Social Security obligations. Retirement benefits for active workers depend on the realization of the future economy-wide wage level. If wages and stock returns correlate positively over the long run, retirement benefits contain an aggregate risk component and should therefore be discounted at a rate that accounts for that risk.
} 


\section{Conclusions}

In this chapter, we review the theoretical and empirical literature that models a worker's life-cycle earnings and identifies appropriate discount rates to translate those cash flows into a measure of human capital value. The main points of our discussion can be summarized as follows:

1. Due to various market imperfections, there is no trading in explicit claims on future labor income flows. Since workers are exposed to labor income shocks that cannot be hedged with traded assets, the valuation of human capital is specific to the person who embodies the set of values and skills that contribute to making him productive. Hence, we focus on the worker's private valuation of human capital, defined as the implicit value of future earnings discounted at the worker's intertemporal marginal rate of substitution.

2. A vast literature abstracts from work/leisure decisions and models the worker's earnings as an exogenous univariate process that includes a deterministic component as well as persistent (or permanent) and transient shocks. The estimated earnings process discounted at risk-adjusted rates implies that the value of human capital exhibits a hump-shaped profile over the worker's life cycle. Variation in workers' characteristics such as gender, race, risk preferences, marital status, and education account for a great deal of cross-sectional heterogeneity in human capital valuation.

3. A new wave of research explores the economic sources of risk that underlie shocks to earnings and explicitly models the worker's work-leisure and retirement decisions. This literature has been successful at linking labor income fluctuations to shocks to individual productivity, health shocks, job arrival shocks, and firm-level shocks that may lead to job creation or destruction. In turn, these findings help us better understand the sources of risk in a worker's human capital.

4. The value of a person's human capital depends on the education and training that he acquires over life. The benefits are not limited to college education, as recent research stresses the importance of early childhood investment. The rise in college tuition has deepened concerns that people might be obtaining a sub-optimal level and quality of education, and that they could be forced to consume less and work more during their college years. While the evidence on the effect of borrowing limits on college attendance is mixed, credit constraints are likely to be a bigger impediment for early childhood investment. Public policy experiments suggest that social programs that help finance early education have a larger impact on earnings mobility than an increase in college subsidies.

5. There is little evidence of contemporaneous correlation between labor income fluctuations and stock market returns. In contrast, long-run dependencies between labor 
income and stock returns are a potentially important channel that exposes human capital to aggregate economic risk. These low-frequency comovements are hard to quantify with data that span a relatively short period of time, but in model calibrations they can have a significant impact on the valuation of human capital. When the stock and labor markets comove in the long-run, human capital acquires stock-like properties, especially for young workers who are exposed the most to long-run labor income risk.

In spite of the progress that has been made, much work is still to be done. Issues that are worth further investigation include the following:

1. While our discussion focuses on private valuation, human capital could also include a significant social component. For instance, an increase in the human capital of an individual worker might create positive non-pecuniary externalities, such as better citizens or lower crime, and raise the productivity of other workers around him and therefore increase aggregate productivity in the economy. Related, in the presence of complementarity in the production factors, wider availability of human capital might induce firms to increase their investment in physical capital and thus result in higher wages (e.g., Acemoglu 1996). For these reasons, the social return to human capital could exceed the private return. In contrast, if education is merely a signal of a worker's ability, then the social return to the investment in education could be lower than the private return, because high-ability workers might generate a negative externality for other workers by pursuing more schooling, which will be rewarded with higher wages.

2. The measure of human capital that we discuss here is based on the valuation of lifetime earnings generated by the worker. However, earnings are an imprecise measure of a worker's skills. While attributing differences in earnings, and therefore the value of human capital, to unobserved skill heterogeneity is a useful starting point, this approach is reductive (e.g., Acemoglu and Autor 2011). For instance, differences in compensation may be explained by hard-to-measure job characteristics that could make a job appealing, even if it pays a low salary. Second, the productivity of two jobs may be different, and workers in those two positions could be paid a different salary in spite of having similar skills. Third, workers might face wage discrimination due to employers' prejudices against, e.g., race, gender, or religion. These considerations suggest that human capital valuation should be based on a broader measure of cash flows associated with workers' output, rather than on observed earnings.

3. Over the years, education has been one of the main targets of social policies aimed at fostering the production of human capital and bridging income inequality. The success of these programs hinges on the ability of policymakers to use limited resources effectively. Understanding how to better design such programs is the topic of much ongoing research, including many of the contributions we discuss here. An important

\footnotetext{
${ }^{11}$ See, e.g., Lange and Topel (2006) for a review of the literature on the social returns to the accumulation of human capital and, in particular, the social returns to education.
} 
part of this agenda is the study of the role of education in the production of human capital (early childhood investment versus schooling and subsequent job training). Related, possible credit constraints motivate policies (e.g., student loans and various subsidies) that promote the accessibility of education. A better grasp of the human capital production function and skill formation could form the basis for more effective school programs and curricula, teachers' training, and investment in premises and teaching technology.

4. Finally, the studies that we review suggest that there is a linkage between health shocks and earnings. More work on this topic could help policymakers develop improved health and preventive care programs aimed at raising the private and social value of human capital and improving the management of human capital risks.

\section{References}

Abowd J, Card D. 1989. On The Covariance Structure of Earnings and Hours Change. Econometrica 57(2):411-445

Acemoglu D. 1996. A Microfoundation For Social Increasing Returns in Human Capital Accumulation. Q. J. Econ. 111:779-804

Acemoglu D, Autor D. 2011. Lectures in Labor Economics. Lecture Notes, MIT

Almond D, Currie J. 2011. Human capital development before age five. In Handbook of Labor Economics, Vol. 4(B), ed. OC Ashenfelter, D Card, pp. 1315-1486. Amsterdam: Elsevier

Almond D, Mazumder B. 2011. Health, capital and the prenatal environment: the effect of Ramadan observance during pregnancy. Am. Econ. J.: Applied Economics 3:56-85

Altonji JG, Smith A, Vidangos I. 2013. Modelling earning dynamics. Econometrica 81(4)1395-1454

Athreya K, Ionescu F, Neelakantan U. 2013. Risky, lumpy human capital investment and life-cycle household portfolios. Work. Pap., Fed. Reserve Board and Fed. Reserve Bank Richmond

Attanasio O. 1995. The intertemporal allocation of consumption: theory and evidence. Carnegie-Rochester Conference Series on Public Policy 42:39-89

Au DWH, Crossley TF, Schellhorn M. 2005. The effect of health changes and long-term health on the work activity of older Canadians. Health Econ. 14(10):999-1018.

Bansal R, Kiku D, Shaliastovich I, Yaron A. 2013. Volatility, the macroeconomy and asset prices. J. Finance, forthcoming 
Barker DJ, Osmond C. 1986. Infant mortality, childhood nutrition and ischemic heart disease in England and Wales. Lancet 1:1077-1081

Basak S, Cuoco D. 1998. An equilibrium model with restricted stock market participation, Rev. Financ. Studies 11:309-341

Baxter M, Jermann U. 1997. The international diversification puzzle is worse than you think. Am. Econ. Rev. 87:170-180

Becker G. 1964. Human Capital: A Theoretical and Empirical Analysis, with Special Reference to Education. Chicago, IL: The University of Chicago Press.

Ben-Porath Y. 1967. The production of human capital and the life cycle of earnings. J. Pol. Econ. 75:352-65

Benzoni L, Chyruk O. 2009. Investing over the life cycle with long-run labor income risk. Economic Perspectives 33(3):2-16

Benzoni L, Collin-Dufresne P, Goldstein RS. 2007. Portfolio choice over the lifecycle when the stock and labor markets are co-integrated. J. Finance 62(5):2123-2167

Brown JR, Fang F, Gomes F. 2013. Risk and returns to education. Work. Pap., Univ of Illinois at Urbana-Champaign, Univ of Michigan, London Business School.

Cameron S, Heckman JJ. 1998. Life cycle schooling and dynamic selection bias: models and evidence for five cohorts of American males. J. Pol. Econ. 106:262-333

Campbell J. 1996. Understanding risk and return. J. Pol. Econ. 104:298-345

Campbell J, Cocco J, Gomes FJ, Maenhout P. 2001. Investing retirement wealth: a lifecycle model. In Risk Aspects of Investment-Based Social security reform, ed. J Campbell, M Feldstein. Chicago, IL: University of Chicago Press

Card D. 1999. The Causal Effect of Education on Earnings. In Handbook of Labor Economics, Volume 3, ed. O Ashen, D Card. Elsevier Science.

Carroll C, Samwick A. 1997. The nature of precautionary wealth. J. Monet. Econ. 40:41-71

Cho I, Kreps DM. 1987. Signaling Games and Stable Equilibria. Q. J. Econ. 102(2):179-222

Cocco J, Gomes F. 2012. Longevity risk, retirement savings and financial innovation. J. Financ. Econ. 103(3):507-529

Cocco J, Gomes FJ, Maenhout P. 2005. Consumption and portfolio choice over the lifecycle. Rev. Financ. Studies 18:491-533

Cunha F, Heckman JJ. 2007. The technology of skill formation. Am. Econ. Rev. PËP $97(2): 31-47$ 
Cunha F, Heckman JJ. 2008. Formulating, identifying and estimating the technology of cognitive and noncognitive skill formation. Journal of Human Resources 43(4):738-782

Cunha F, JJ Heckman, LJ Lochner, DV Masterov. 2006. Interpreting the evidence on life cycle skill formation. In Handbook of the Economics of Education, ed. EA Hanushek, F Welch, Chapter 12, 697-812. Amsterdam: North-Holland

Cunha F, Heckman JJ, Schennach SM. 2010. Estimating the technology of cognitive and noncognitive skill formation. Econometrica 78(3):883-931

Currie J, Madrian BC. 1999. Health, health insurance and the labor market. In Handbook of Labor Economics, Vol. 3, ed. OC Ashenfelter, D Card, pp. 3309-3416. Amsterdam: Elsevier

Dahl G, Lochner L. 2012. The impact of family income on child achievement: evidence from the Earned Income Tax Credit. Am. Econ. Rev. 102(5):1927-1956

Davis S, Willen P. 2000. Occupation-level income shocks and asset returns: their covariance and implications for portfolio choice. NBER Work. Pap. 7905

De Nardi M, French E, Jones JB. 2013. Medicaid insurance in old age. NBER Work. Pap. 19151

Disney R, Emmerson C, Wakefield M. 2006. Ill health and retirement in Britain: a panel data-based analysis. J. Health Econ. 25(4):621-649

Dybvig P, Liu H. 2010. Lifetime consumption and investment: retirement and constrained borrowing. J. Econ. Theory 145:885-907

Farhi E, Panageas S. 2007. Saving and investing for early retirement: a theoretical analysis. J. Financ. Econ. 83(1):87-121

French E. 2005. The effects of health, wealth, and wages on labor supply and retirement behavior. Rev. Econ. Studies 72(2):395-427

French E, Jones JB. 2011. The effects of health insurance and self-insurance on retirement behavior. Econometrica 79(3):693-732

Geanakoplos J, Zeldes SP. 2010. Market valuation of accrued social security benefits. In Measuring and Managing Federal Financial Risk, ed Lucas D, pp 213-233. Chicago, IL: University of Chicago Press.

Gomes F, Michaelides A. 2005. Optimal life-cycle asset allocation: understanding the empirical evidence. J. Finance 60:869-904

Gourinchas P, Parker J. 2002. Consumption over the life cycle. Econometrica 70:47-89 
Grossman M. 1975. The correlation between health and schooling. In Household production and consumption, ed. NE Terleckyj, pp. 147-211. New York: Columbia University Press

Guvenen F. 2009. An empirical investigation of labor income processes. Rev. Econ. Dynamics 12:58-79

Haliassos M, Michaelides A. 2003. Portfolio choice and liquidity constraints. International Econ. Rev. 44:143-177

Hause JC. 1980. The fine structure of earnings and the on-the-job training hypothesis. Econometrica 48:1013-1029

Haveman RR, Wolfe B, Huang FM. 1994. Market work, wages and men's health. J. Health Econ. 13:163-182

He H, Pearson N. 1991. Consumption and portfolio policies with incomplete markets and short-sale constraints: the infinite dimensional case, J. Econ. Theory 54: 259-304

Heaton J, Lucas DJ. 1997. Market frictions, savings behavior, and portfolio choice, Macroeconomic Dynamics 1:76-101

Hubbard G, Skinner JS, Zeldes S. 1995. Precautionary Saving and Social Insurance. J. Political Economy 103:360-399

Huggett M, Kaplan G. 2013. The money value of a man. Work. Pap., Georgetown Univ. and Princeton Univ.

Huggett M, Yaron A, Ventura G. 2006. Human capital and earnings distribution dynamics. J. Monet. Econ. 53:265-290

Huggett M, Yaron A, Ventura G. 2011. Sources of lifetime inequality. Am. Econ. Rev. 101:2923-2954

Karatzas I, Lehoczky J, Shreve S, Xu G. 1991. Martingale and duality methods for utility maximization in an incomplete market. SIAM J. Control Optim. 29:702-730

Keane M, Wolpin KI. 2001. The effect of parental transfers and borrowing constraints on educational attainment. Int. Econ. Rev. 42:1051-103

Kraemer S. 2000. The fragile male. BMJ 321(7276):1609-1612

Lange F, Topel R. 2006. The Social Value of Education and Human Capital. In Handbook of the Economics of Education, Vol. 1, ed Hanushek EA, Welch F. Amsterdam: Elsevier

Lee L. 1982. Health and wages: a simultaneous equation model with multiple discrete indicators. Int. Econ. Rev. 23:199-221 
Lillard LA, Weiss YA. 1979. Components of variation in panel earnings data: American scientists, 1960-70. Econometrica 47:437-454

Lochner L, Monge-Naranjo A. 2011. The nature of credit constraints and human capital. Am. Econ. Rev. 101:2487-529

Lochner L, Monge-Naranjo A. 2012. Credit constraints in education. Annu. Rev. Econ. $4: 225-256$

Low H, Meghir C, Pistaferri L. 2010. Wage risk and employment risk over the life cycle. Am. Econ. Rev. 100(4):1432-1467

Lucas D, Zeldes SP. 2006. Valuing and hedging defined benefit pension obligations - the role of stocks revisited. Work. Pap., Northwestern Univ., Columbia Univ.

Lucas DJ, Zeldes SP. 2009. How should public pension plans invest? Am. Econ. Rev. PEP. 99(2):527-532

Lustig H, Nieuwerburgh S. 2005. The returns on human capital: good news on Wall street is bad news on main street, Rev. Financ. Studies, forthcoming.

Lynch AW, Tan S. 2011. Labor income dynamics at business cycle frequencies: implications for portfolio choice. J. of Financ. Econ. 101(2):333-359

MaCurdy T. 1982. The Use of Time Series Processes to Model the Error Structure of Earnings in a Longitudinal Data Analysis. J. of Econometrics 18:83-114

Meghir C, Pistaferri L. 2004. Income variance dynamics and heterogeneity. Econometrica $72(1): 1-32$

Mankiw NG, Zeldes SP. 1991. The consumption of stockholders and nonstockholders. J. Financ. Econ. 29(1):97-112

Palacios-Huerta I. 2003. An empirical analysis of the risk properties of human capital returns. Am. Econ. Rev. 93:948-964

Perri TJ. 1984. Health status and schooling decisions of young men. Economics of Educ. Rev. 3:207-213

Restuccia D, Urrutia C. 2004. Intergenerational Persistence of Earnings: The Role of Early and College Education. Am. Econ. Rev. 94(5):1354-1378

Ríos Rull JV. 1996. Life-cycle economies and aggregate fluctuations. Rev. Econ. Studies 63:465-490

Riphahn RT. 1999. Income and employment effects of health shocks a test case for the German welfare state. J. Popul. Econ. 12(3):363-389. 
Roussanov N. 2010. Human capital investment and portfolio choice over the life-cycle. Work. Pap., The Wharton School, Pennsylvania Univ.

Saks RE, Shore SH. 2005. Risk and career choice. Advances in Economic Analysis and Policy 5, Article 7

Santos T, Veronesi P. 2006. Labor income and predictable stock returns. Rev. Financ. Studies 19:1-44

Smith JP. 1999. Healthy bodies and thick wallets: the dual relation between health and economic status. J. of Economic Perspectives 13(2):145-166

Smith JP. 2009. The impact of childhood health on adult labor market outcomes. Rev. Economics and Statistics: 91(3):478-489.

Spence M. 1973. Job Market Signaling. Q. J. Econ. 87(3):355-374

Storesletten K, Telmer C, Yaron A. 2004. Cyclical dynamics of idiosyncratic labor market risk. J. Pol. Econ. 112(3):695-717

Storesletten K, Telmer C, Yaron A. 2007. Asset pricing with idiosyncratic risk and overlapping generations. Rev. Econ. Dynamics 10(4):519-548

Svensson LEO, Werner IM. 1993. Nontraded assets in incomplete markets: Pricing and portfolio choice. European Econ. Rev. 37:1149-1168.

van der Klaauw W, Wolpin K. 2008. Social security and the savings and retirement behavior of low income households. J. Econometrics 145(1-2):21-42

Viceira, L. 2001. Optimal portfolio choice for long-horizon investors with nontradable labor income. J. Finance 56:433-470

Wadsworth ME. 1986. Serious illness in childhood and its association with later-life achievement. In Class and Health, ed. R Wilkinson. London: Tavistock Publications

Wolfe B. 1985. The influence of health on school outcomes: a multivariate approach. Medical Care 23:1127-1138

Yogo M. 2007. Portfolio choice in retirement: health risk and the demand for annuities, housing, and risky assets. Fed. Reserve Bank Minneapolis Work. Pap. 


\section{Working Paper Series}

A series of research studies on regional economic issues relating to the Seventh Federal Reserve District, and on financial and economic topics.

Examining Macroeconomic Models through the Lens of Asset Pricing

WP-12-01

Jaroslav Borovička and Lars Peter Hansen

The Chicago Fed DSGE Model

WP-12-02

Scott A. Brave, Jeffrey R. Campbell, Jonas D.M. Fisher, and Alejandro Justiniano

Macroeconomic Effects of Federal Reserve Forward Guidance

WP-12-03

Jeffrey R. Campbell, Charles L. Evans, Jonas D.M. Fisher, and Alejandro Justiniano

Modeling Credit Contagion via the Updating of Fragile Beliefs

WP-12-04

Luca Benzoni, Pierre Collin-Dufresne, Robert S. Goldstein, and Jean Helwege

Signaling Effects of Monetary Policy

WP-12-05

Leonardo Melosi

Empirical Research on Sovereign Debt and Default

WP-12-06

Michael Tomz and Mark L. J. Wright

Credit Risk and Disaster Risk

WP-12-07

François Gourio

From the Horse's Mouth: How do Investor Expectations of Risk and Return

Vary with Economic Conditions?

WP-12-08

Gene Amromin and Steven A. Sharpe

Using Vehicle Taxes To Reduce Carbon Dioxide Emissions Rates of

New Passenger Vehicles: Evidence from France, Germany, and Sweden

WP-12-09

Thomas Klier and Joshua Linn

Spending Responses to State Sales Tax Holidays

WP-12-10

Sumit Agarwal and Leslie McGranahan

Micro Data and Macro Technology

WP-12-11

Ezra Oberfield and Devesh Raval

The Effect of Disability Insurance Receipt on Labor Supply: A Dynamic Analysis

WP-12-12

Eric French and Jae Song

Medicaid Insurance in Old Age

WP-12-13

Mariacristina De Nardi, Eric French, and John Bailey Jones

WP-12-14

Fetal Origins and Parental Responses

Douglas Almond and Bhashkar Mazumder 


\section{Working Paper Series (continued)}

Repos, Fire Sales, and Bankruptcy Policy

WP-12-15

Gaetano Antinolfi, Francesca Carapella, Charles Kahn, Antoine Martin,

David Mills, and Ed Nosal

Speculative Runs on Interest Rate Pegs

The Frictionless Case

WP-12-16

Marco Bassetto and Christopher Phelan

Institutions, the Cost of Capital, and Long-Run Economic Growth:

Evidence from the 19th Century Capital Market

WP-12-17

Ron Alquist and Ben Chabot

Emerging Economies, Trade Policy, and Macroeconomic Shocks

WP-12-18

Chad P. Bown and Meredith A. Crowley

The Urban Density Premium across Establishments

WP-13-01

R. Jason Faberman and Matthew Freedman

Why Do Borrowers Make Mortgage Refinancing Mistakes?

WP-13-02

Sumit Agarwal, Richard J. Rosen, and Vincent Yao

Bank Panics, Government Guarantees, and the Long-Run Size of the Financial Sector:

Evidence from Free-Banking America

Benjamin Chabot and Charles C. Moul

WP-13-03

Fiscal Consequences of Paying Interest on Reserves

WP-13-04

Marco Bassetto and Todd Messer

Properties of the Vacancy Statistic in the Discrete Circle Covering Problem

WP-13-05

Gadi Barlevy and H. N. Nagaraja

Credit Crunches and Credit Allocation in a Model of Entrepreneurship

WP-13-06

Marco Bassetto, Marco Cagetti, and Mariacristina De Nardi

Financial Incentives and Educational Investment:

The Impact of Performance-Based Scholarships on Student Time Use

WP-13-07

Lisa Barrow and Cecilia Elena Rouse

The Global Welfare Impact of China: Trade Integration and Technological Change

WP-13-08

Julian di Giovanni, Andrei A. Levchenko, and Jing Zhang

Structural Change in an Open Economy

WP-13-09

Timothy Uy, Kei-Mu Yi, and Jing Zhang

The Global Labor Market Impact of Emerging Giants: a Quantitative Assessment

WP-13-10

Andrei A. Levchenko and Jing Zhang 


\section{Working Paper Series (continued)}

Size-Dependent Regulations, Firm Size Distribution, and Reallocation

WP-13-11

François Gourio and Nicolas Roys

Modeling the Evolution of Expectations and Uncertainty in General Equilibrium

WP-13-12

Francesco Bianchi and Leonardo Melosi

Rushing into the American Dream? House Prices, the Timing of Homeownership, and the Adjustment of Consumer Credit

WP-13-13

Sumit Agarwal, Luojia Hu, and Xing Huang

The Earned Income Tax Credit and Food Consumption Patterns

WP-13-14

Leslie McGranahan and Diane W. Schanzenbach

Agglomeration in the European automobile supplier industry

WP-13-15

Thomas Klier and Dan McMillen

Human Capital and Long-Run Labor Income Risk

WP-13-16

Luca Benzoni and Olena Chyruk

The Effects of the Saving and Banking Glut on the U.S. Economy

WP-13-17

Alejandro Justiniano, Giorgio E. Primiceri, and Andrea Tambalotti

A Portfolio-Balance Approach to the Nominal Term Structure

WP-13-18

Thomas B. King

Gross Migration, Housing and Urban Population Dynamics

WP-13-19

Morris A. Davis, Jonas D.M. Fisher, and Marcelo Veracierto

Very Simple Markov-Perfect Industry Dynamics

WP-13-20

Jaap H. Abbring, Jeffrey R. Campbell, Jan Tilly, and Nan Yang

Bubbles and Leverage: A Simple and Unified Approach

WP-13-21

Robert Barsky and Theodore Bogusz

The scarcity value of Treasury collateral:

Repo market effects of security-specific supply and demand factors

Stefania D'Amico, Roger Fan, and Yuriy Kitsul

WP-13-22

Gambling for Dollars: Strategic Hedge Fund Manager Investment

WP-13-23

Dan Bernhardt and Ed Nosal

Cash-in-the-Market Pricing in a Model with Money and

Over-the-Counter Financial Markets

WP-13-24

Fabrizio Mattesini and Ed Nosal

An Interview with Neil Wallace

WP-13-25

David Altig and Ed Nosal 


\section{Working Paper Series (continued)}

Firm Dynamics and the Minimum Wage: A Putty-Clay Approach

WP-13-26

Daniel Aaronson, Eric French, and Isaac Sorkin

Policy Intervention in Debt Renegotiation:

Evidence from the Home Affordable Modification Program

WP-13-27

Sumit Agarwal, Gene Amromin, Itzhak Ben-David, Souphala Chomsisengphet, Tomasz Piskorski, and Amit Seru

The Effects of the Massachusetts Health Reform on Financial Distress

WP-14-01

Bhashkar Mazumder and Sarah Miller

Can Intangible Capital Explain Cyclical Movements in the Labor Wedge?

WP-14-02

François Gourio and Leena Rudanko

Early Public Banks

William Roberds and François R. Velde

WP-14-03

Mandatory Disclosure and Financial Contagion

WP-14-04

Fernando Alvarez and Gadi Barlevy

The Stock of External Sovereign Debt: Can We Take the Data at 'Face Value'?

WP-14-05

Daniel A. Dias, Christine Richmond, and Mark L. J. Wright

Interpreting the Pari Passu Clause in Sovereign Bond Contracts:

It's All Hebrew (and Aramaic) to Me

WP-14-06

Mark L. J. Wright

AIG in Hindsight

WP-14-07

Robert McDonald and Anna Paulson

WP-14-08

On the Structural Interpretation of the Smets-Wouters "Risk Premium" Shock

Jonas D.M. Fisher

Human Capital Risk, Contract Enforcement, and the Macroeconomy

WP-14-09

Tom Krebs, Moritz Kuhn, and Mark L. J. Wright

Adverse Selection, Risk Sharing and Business Cycles

WP-14-10

Marcelo Veracierto

Core and 'Crust': Consumer Prices and the Term Structure of Interest Rates

WP-14-11

Andrea Ajello, Luca Benzoni, and Olena Chyruk

The Evolution of Comparative Advantage: Measurement and Implications

WP-14-12 Andrei A. Levchenko and Jing Zhang 


\section{Working Paper Series (continued)}

Saving Europe?: The Unpleasant Arithmetic of Fiscal Austerity in Integrated Economies Enrique G. Mendoza, Linda L. Tesar, and Jing Zhang

WP-14-13

Liquidity Traps and Monetary Policy: Managing a Credit Crunch

WP-14-14

Francisco Buera and Juan Pablo Nicolini

Quantitative Easing in Joseph’s Egypt with Keynesian Producers

Jeffrey R. Campbell

WP-14-15

Constrained Discretion and Central Bank Transparency

WP-14-16

Francesco Bianchi and Leonardo Melosi

Escaping the Great Recession

WP-14-17

Francesco Bianchi and Leonardo Melosi

WP-14-18

More on Middlemen: Equilibrium Entry and Efficiency in Intermediated Markets

Ed Nosal, Yuet-Yee Wong, and Randall Wright

Preventing Bank Runs

WP-14-19

David Andolfatto, Ed Nosal, and Bruno Sultanum

The Impact of Chicago's Small High School Initiative

WP-14-20

Lisa Barrow, Diane Whitmore Schanzenbach, and Amy Claessens

Credit Supply and the Housing Boom

WP-14-21

Alejandro Justiniano, Giorgio E. Primiceri, and Andrea Tambalotti

WP-14-22

The Effect of Vehicle Fuel Economy Standards on Technology Adoption

Thomas Klier and Joshua Linn

What Drives Bank Funding Spreads?

WP-14-23

Thomas B. King and Kurt F. Lewis

Inflation Uncertainty and Disagreement in Bond Risk Premia

WP-14-24

Stefania D'Amico and Athanasios Orphanides

Access to Refinancing and Mortgage Interest Rates:

WP-14-25

HARPing on the Importance of Competition

Gene Amromin and Caitlin Kearns

Private Takings

WP-14-26

Alessandro Marchesiani and Ed Nosal

WP-14-27

Momentum Trading, Return Chasing, and Predictable Crashes

Benjamin Chabot, Eric Ghysels, and Ravi Jagannathan

Early Life Environment and Racial Inequality in Education and Earnings in the United States

WP-14-28

Kenneth Y. Chay, Jonathan Guryan, and Bhashkar Mazumder 


\section{Working Paper Series (continued)}

Poor (Wo)man's Bootstrap

WP-15-01

Bo E. Honoré and Luojia Hu

Revisiting the Role of Home Production in Life-Cycle Labor Supply

WP-15-02

R. Jason Faberman

Risk Management for Monetary Policy Near the Zero Lower Bound

WP-15-03

Charles Evans, Jonas Fisher, François Gourio, and Spencer Krane

Estimating the Intergenerational Elasticity and Rank Association in the US:

Overcoming the Current Limitations of Tax Data

WP-15-04

Bhashkar Mazumder

External and Public Debt Crises

WP-15-05

Cristina Arellano, Andrew Atkeson, and Mark Wright

The Value and Risk of Human Capital

WP-15-06

Luca Benzoni and Olena Chyruk 